\title{
The Decision-Making Process in Administrative Cases
}

In domestic law the approach dominates whereby analysis of existing administrative proceedings is carried out by considering their stages, as "complexes of sequential proceedings, united by a common aim, content, functional orientation and circle of participants". Methodological validity of this approach is obvious.

The value of procedural stages is determined primarily by the fact that they reflect the logical sequence of the administrative process. Each stage has its clear procedural purposes. Remedial actions at each stage are united by common goals, which, in turn, serve the general purpose of the proceeding. Each stage is characterised by specific features related to the time and forms of implementation, the list of participants, their legal status, available decisions etc. Disclosure of the procedural stages allows us, on the one hand, to consider it in its entirety, consistency and dynamics while on the other - to focus on local issues that arise during the procedural activities.

O. Kuzmenko claims that he compulsory presence of law-regulated stages of administrative proceedings is a common procedural safeguard that determines the activity of public administration ${ }^{2}$. Process stages are important organic elements that characterise the structure of each proceeding in particular and the administrative process, adds M. Tishchenko ${ }^{3}$. The content of administrative proceedings can be explored primarily through analysis of their stages. To characterise a particular administrative proceeding generally means to analyse all its stages, concludes V. Kolpakov ${ }^{4}$.

1 Anna Gurzhii, PhD, Administrative, Financial and Informational Law Department, Kyiv National University of Trade and Economics.

2 O.V. Kuzmenko, Teoretychni zasady administratyvnoho protsesu, Kyiv: Atika 2005, p. 146, 147.

3 M. Tishchenko [in:] Administratyvne pravo Ukrainy, Yu. P. Bytiaka (eds.), Kiev: Yurinkom-Inter 2006, p. 231.

4 V.K. Kolpakov, Administratyvne pravo Ukrainy, Yurinkom Inter 2000, p. 330. 
However, despite the overall recognition of high importance of procedural stages, modern lawyers for many years have been unable to agree on their number and content in the administrative-delict process.

For example, A. Agapov distinguishes only two stages of the administrative-delict proceeding: procedural and executive ${ }^{5}$.

On the basis of the three-stage concept for administrative and tort proceedings, O. Riabchenko and A. Yatsenkomark single out the stage of drawing up a report concerning the administrative offense, the stage of considering the caseand that of the appeal decision.

According to V. Aver'yanov, the administrative-delict proceeding consists of four main stages: initiation of an administrative case and its investigation; considering the case and making the decision; appeal (protest) revision of the case; implementation of the final decision and applying an administrative penalty ${ }^{6}$. M. Zavalnyi also identifies four stages of the administrative-delict proceeding which demonstrates a slightly different perspective on their sequence. From his point of view, the "appeal" stage is optional, and must therefore follow the execution step ${ }^{7}$.

D. Bahrah, A. Koryenyev, I. Kartuzova, L. Koval and S. Stetsenkoassert claim that proceedings in cases of administrative offenses are characterised by at least five stages. However, these scientists agree only on the number of stages of the administrative-delict process while their understanding of their content differs greatly. In brief, the "five-element" classification stages can be summarised as follows: 1) the proceeding initiation stage (D. Bahrah, A. Koryenyev, I. Kartuzova, S. Stetsenko), the administrative investigation stage (L. Koval) ${ }^{8}$; 2) clarifying the facts of the case (D. Bahrah, A. Koryenyev) and the initiation of an administrative case (L. Koval), the stage of hearing the case (S. Stetsenko) and administrative investigation (I. Kartuzova) ${ }^{9} ; 3$ ) the proceeding stage (A. Koryenyev), hearing the case, making the decision, bringing its content to the attention of the interested parties (D. Bahrah, I. Kartuzova, L. Koval), making a decision in the case (S. Stetsenko $)^{10}$; 4) making a decision in the case (A. Koryenyev), review of the resolution of the case (D. Bahrah, I. Kartuzova), appealing against the decision in the case (L. Koval), implementation of the decision in the case

5 A.B. Ahapov, Admynystratyvnaia otvetstvennost, Moscow: Statut 2000, p. 233-234.

6 Administratyvne pravo Ukrainy. Akademichnyi kurs, Zahalna chastyna, vol. 1, V.B. Averianova (ed.), Kyiv: Iurydychna dumka 2004, p. 519.

7 M.V. Zavalnyi, Sutnist ta zmist administratyvno-deliktnoho provadzhennia, "Mytna sprava" 2011, No. 2 (74), p. 208.

8 S.H. Stetsenko, Administratyvne pravo Ukrainy, Kyiv: Atika 2007, p. 269-270.

9 S.V. Kyvalov, V. B. Averianov, E.V. Dodyn, Admynystratyvnoe pravo Ukraynbl, S.V. Kyvalova (ed.), Cherson: Odyssei 2005, p. 272.

10 D.N. Bakhrakh, Admynystratyvnaia otvetstvennost hrazhdan $v$ SSSR, Sverdlovsk: Ural. un-t 1989, p. 118. 
(S. Stetsenko $)^{11}$ 5) making the decision in the case (D. Bahrah, I. Kartuzova, L. Koval, A. Koryenyev), appealing against the decision in the case (S. Stetsenko) $)^{12}$.

Making references to current legislation, enforcement practices and modern scientific research, V. Kolpakov, O. Chernovskyy and V. Hordyeyev outline six separate stages, which consist of 19 phases. From their point of view, the administrative-delict procedure comprises the steps of: initiating the proceeding, administrative investigation, proceeding in the case, making the decision, review of the decision, and implementation of the decision $^{13}$.

Finally, the Russian lawyer V. Yusupov distinguishes seven stages of the administrative-delict process: 1 ) initiation of the proceeding; 2) collection and study of relevant information; 3) preliminary investigation; 4) choice of law to be applied; 5) making the decision (by competent trial bodies); 6) consideration of complaints and adoption of the final decision; 7) implementation of the decision ${ }^{14}$.

As for the broad variety of views on the structure of the administrative-delict process, the following should be said: as in most cases, the differences between the various scientific approaches are not fundamental, they should not be opposed to each other. The wide range of ideas about the stages of the administrative-delict process is determined by specific individual understanding of the nature of the procedural stages, their inherent characteristics as well as their legal and factual content. Allocations of stages depend a lot on the subject of scientific research. It is clear that researchers of offenses and cases providing for a simplified procedure release fewer stages than those engaged in issues of administrative proceedings in the courts.

In short, almost every kind of scientifically based view on the structure of the administrative-delict process can be justified. Depending on the objectives of particular research, the number of its stages can be increased or decreased; such reasearch work can suggest different numbers of steps, which can be named differently as well. Above all, the outlined stages should reflect the nature of the administrative-delict process, fully disclosing the content of all the implemented proceedings and steps.

11 A.P. Korenev, Normb admynystratyvnoho prava y ykh prymenenye, Moscow: Yuryd. lyt. 1978, p. 99.

12 L.V. Koval, Administratyvne pravo Ukrainy. Zahalna chastyna, Kyiv: Osnovy 1994, p. 112.

13 V.K. Kolpakov, O.K. Chernovskyi, V.V. Hordieiev, Porushennia pravyl dorozhnoho rukhu: koliziinist novel i pravove rehuliuvannia, Chernivtsi: Chernivetskyi natsionalnyi universytet 2010, p. 13.

14 V.A. Yusupov, Pravoprymenytelnaia deiatelnost orhanov hosudarstvennoho upravlenyia, Moscow: Yuryd. lyt. 1979, p. 34-35. 
However, when allocating the structural elements of administrative proceedings it is very important to follow the rules of formal logic, legal axioms and established views on these or other related procedural phenomena. As analysis shows, not all scientists strictly follow this rule.

In our view, highly debatable are ideas concerning: providing a separate "procedural" stage in the administrative-delict process; the absence of the implementation stage in its structure; the existence of stages which do not provide for the collection of procedural acts; the implementation of the appeal (protest) stage after the stage of providing the final decision, etc.

In particular, it is clear that over-generalisation of procedural stages, reducing them to procedural and enforcement "units" cannot form a clear picture of the structure of the administrative proceedings and the content of its individual components. Moreover, the isolation of the so-called "procedural" stage contradicts traditional notions of administrative procedure as: "a special order of resolving administrative cases not connected with coercive measures"15. In our opinion, putting the autonomous administrative proceedings (besides, not criminal) in the framework of a single stage of the administrative-delict process is unreasonable both from theoretical and practical points of view.

Also, one cannot agree with the idea that the administrative-delict process is completed with the adoption of an enforcement act and does not cover the stage of its implementation. The main argument in favour of this approach according to its adherents is the fact that under the current paradigm of the administrative process, its structure, along with the rule-making, control, registration and other types of tort proceedings it is allocated an implementation procedure. Given the existence of self-enforcement proceedings, they denied the possibility of "executive" stages in other administrative proceedings.

Meanwhile, according to statistics, the majority (over 65\%) of regulation on administrative offenses is carried out voluntarily. The relevant procedures are not coercive, and therefore cannot be covered by the scope of the "implementation" proceeding. Thus, their exclusion from the structure of the administrative-delict process seems impractical. In fact it would mean that the stage of voluntary compliance penalties is dropped from all existing proceedings.

Given the above considerations, we find appropriate to distinguish five basic stages of the administrative-delict process:

1) preliminary analysis of the situation and initiating the case,

2) administrative investigation,

3) decision in the case,

4) appeal decision in the case,

5) implementation of the decision in the case.

15 A.I. Belenchuk, Administratyvne pravo Ukrainy, Kyiv: Vydavnytstvo ASK 2004, p. 84 . 
Understandably, specific administrative cases may not have all of these stages but only some of them. Strictly speaking, binding are only the first three stages while the rest is not always implemented and optional. However, without their analysis one cannot form a holistic view of the administrative-delict process, of its content, structure and logical order. Consequently, a detailed review is needed of all stages of the proceedings (both core and elective) in the chronological order.

\section{Bibliography}

Administratyvne pravo Ukrainy. Akademichnyi kurs, Zahalna chastyna, vol. 1, V.B. Averianova (ed.), Kyiv: Jurydychna dumka 2004.

Ahapov A.B., Admynystratyvnaia otvetstvennost, Moscow: Statut 2000.

Bakhrakh D.N., Admynystratyvnaia otvetstvennost hrazhdan v SSSR, Sverdlovsk, Ural. un-t 1989.

Belenchuk A.I., Administratyvne pravo Ukrainy, Kyiv: Vydavnytstvo ASK, 2004.

Kolpakov V.K., Chernovskyi O.K., Hordieiev V.V., Porushennia pravyl dorozhnoho rukhu: koliziinist novel i pravove rehuliuvannia, Chernivtsi: Chernivetskyi natsionalnyi universytet, 2010.

Kolpakov V.K., Administratyvne pravo Ukrainy, Yurinkom Inter, 2000.

Korenev A. P., Normol admynystratyvnoho prava y ykh prymenenye, Moscow: Yuryd. lyt., 1978.

Koval L.V., Administratyvne pravo Ukrainy. Zahalna chastyna, Kyiv: Osnovy 1994.

Kuzmenko O.V., Teoretychni zasady administratyvnoho protsesu, Kyiv: Atika 2005.

Kyvalov S.V., Averianov V.B., Dodyn E.V., Admynystratyvnoe pravo Ukraynbl, S.V. Kyvalova (ed.), Cherson: Odyssei 2005.

Stetsenko S.H., Administratyvne pravo Ukrainy, Kyiv: Atika 2007.

Tishchenko M. [in:] Administratyvne pravo Ukrainy, K. Yu. P. Bytiaka (eds.), Yurinkom-Inter 2006.

Yusupov V.A., Pravoprymenytelnaia deiatelnost orhanov hosudarstvennoho upravlenyia, Moscow: Yuryd. lyt. 1979.

Zavalnyi M.V., Sutnist ta zmist administratyvno-deliktnoho provadzhennia, "Mytna sprava" 2011, No. 2 (74).

Abstract

The article investigates the procedural aspect of the administrative proceedings. It showcases current problems as regards the structuring of the administrative-delict process and offers a comparison of some main scientific approaches to the structure of the administrative process. On the basis of analysis of modern administrative doctrine, the new concept is proposed for the administrative proceeding structure.

Keywords: administrative law, public administration, delict, offense, proceeding, decision-making process 
Proces decyzyjny w sprawach administracyjnych

Streszczenie

Autorka analizuje proceduralny aspekt postępowań administracyjnych. Naświetla obecne problemy dotyczące struktury postępowań w przypadku deliktów administracyjnych oraz proponuje porównanie głównych podejść naukowych do struktury postępowania administracyjnego. W artykule przedstawiono również nową koncepcję struktury postępowań na podstawie analizy współczesnej doktryny administracyjnej.

Słowa kluczowe: prawo administracyjne, administracja publiczna, delikt, przestępstwo, postępowanie, proces decyzyjny 